\title{
Desain Alternatif Sistem Ventilasi Udara pada Ruang Muat Kapal Pengangkut Ternak dengan Menggunakan Two-wheel Desiccant
}

\author{
Hadits Shofar Fauzi dan Alam Baheramsyah \\ Jurusan Teknik Sistem Perkapalan, Fakultas Teknologi Kelautan, Institut Teknologi Sepuluh Nopember (ITS) \\ Jl. Arief Rahman Hakim, Surabaya 60111 Indonesia \\ e-mail:alam@its.ac.id
}

\begin{abstract}
Abstrak-Sebagai sarana transportasi yang memuat makhluk hidup berupa hewan ternak, kapal pengangkut ternak membutuhkan desain sistem ventilasi khusus pada ruang muat guna menjaga agar hewan ternak terhindar dari heat stress akibat temperatur dan rasio kelembaban yang tinggi. Salah satu upaya untuk menghindari rasio kelembaban yang tinggi adalah memberikan suplai udara kering dengan menggunakan desiccant. Tujuan skripsi ini adalah merencanakan alternatif sistem ventilasi dengan two-wheel desiccant melalui analisa perhitungan terhadap penurunan rasio kelembaban udara setelah melewati dua rotor desiccant serta pemenuhan kebutuhan alat pemanas dan sistem pendinginnya menggunakan panas gas buang dan air kondensat mesin AC. Dari hasil analisa didapatkan hasil bahwa untuk memberikan suplai udara pada ruang muat sebesar $41221 \mathrm{~m}^{3} / \mathrm{h}$, diperoleh spesifikasi dua rotor desiccant yang memiliki diameter 2190 mm dengan ketebalan $200 \mathrm{~mm}$ untuk menurunkan rasio kelembaban udara luar sebesar $26.1 \mathrm{~g} / \mathrm{gg}_{\mathrm{da}}$ menjadi 14.70 $\mathrm{g}_{\mathrm{w}} / \mathrm{kg}_{\mathrm{da}}$. Temperatur udara hasil dehumidifikasi sebesar $72.8^{\circ} \mathrm{C}$ akan diturunkan menjadi $26^{\circ} \mathrm{C}$ dengan menggunakan koil pendingin dan media pendingin lain berupa air kondensat. Penggunaan air kondensat sebagai media pendingin mampu mengurangi beban pendinginan sebesar $18.41 \mathrm{~kW}$ dari total kebutuhan pendinginan sebesar $490.63 \mathrm{~kW}$, sedangkan untuk kebutuhan pemanas udara reaktivasi sebesar $412.57 \mathrm{~kW}$ akan dipenuhi dengan memanfaatkan daya dari panas gas buang sebesar $440.99 \mathrm{~kW}$.
\end{abstract}

Kata kunci-Ternak, Desiccant, Rasio Kelembaban, Panas Gas Buang, Air Kondensat.

\section{PENDAHULUAN}

$\mathrm{K}$ APAL pengangkut ternak atau livestock carrier merupakan sarana yang vital sebagai penyedia angkutan laut dalam memenuhi kebutuhan ternak dari daerah produsen ke konsumen. Seperti diketahui bahwa kapal jenis ini membawa muatan berupa makhluk hidup. Makhluk hidup tersebut akan berada di dalam ruang muat yang kondisinya tertutup, tanpa ada hubungan dengan lingkungan luar. Dengan demikian maka untuk dapat memenuhi kebutuhan udara bagi hewan - hewan ternak yang diangkut dibuatlah desain ventilasi khusus untuk ruang muat kapal tersebut.

Sistem ventilasi udara alami pada ruang muat kapal pengangkut ternak dianggap kurang efektif karena sistemnya sangat tergantung pada kondisi udara luar terutama untuk temperatur dan kelembabannya [1]. Ketika kondisi udara luar memiliki temperatur dan kelembaban relatif yang tidak nyaman bila dirasakan oleh hewan ternak yang diangkut maka hewan tersebut dapat mengalami stress dan terganggu kesehatannya. Penggunaan desiccant dehumidifier dimaksudkan untuk memberikan suplai udara kering guna mengurangi rasio kelembaban udara pada ruang muat dengan mengacu pada nilai yang disarankan oleh Temperature Humidity Index (THI) [2].

Penggunaan two-wheel Desiccant (skema desikan dengan dua rotor) memungkinkan udara untuk dikondisikan melalui dua tahap dehumidifikasi dimana udara dari luar sebelum dialirkan ke ruang muat diserap terlebih dahulu kelembabannya oleh matrial desiccant, kemudian temperatur keluaran dikondisikan oleh sistem pendingin [3]. Kebutuhan pemanas akan dipenuhi dengan memanfaatkan gas buang main engine, sedangkan kebutuhan pendinginan untuk udara hasil dehumidifikasi sebagian akan dipenuhi dengan memanfaatkan air kondensat mesin Air Conditioner (AC) sebagai media pendingin.

\section{DASAR TEORI}

\section{A. Desiccant Dehumidifier}

Desiccant merupakan salah satu zat higroskopis yang dapat menyerap kelembaban dengan cara menyimpan air di dalam kapiler atau permukaan suatu barang dengan tetap mempertahankan keberadaan molekul air. Zat yang paling umum digunakan sebagai penyusun desiccant adalah silica gel yang merupakan bentuk dari silica dioksida $\left(\mathrm{SiO}_{2}\right)$. Penggunaan desiccants pada dehumidifier digunakan untuk menarik kelembaban dari udara dengan menciptakan daerah tekanan uap rendah pada permukaan materialnya [4].

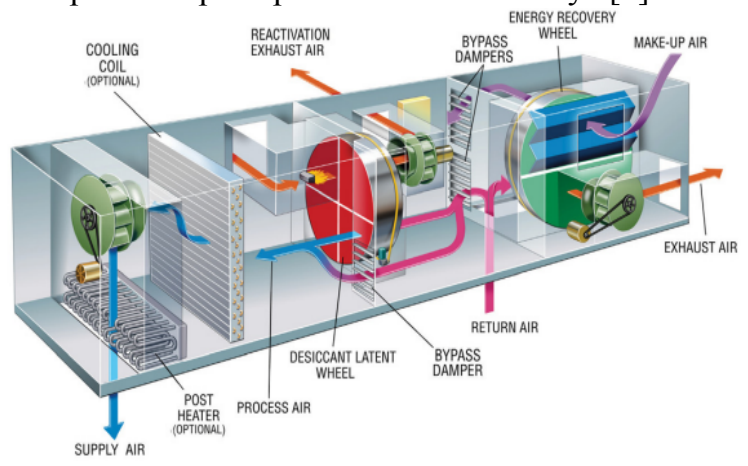

Gambar 1. Konfigurasi two-wheel desiccant 


\section{B. Heat Stress pada Hewan Ternak}

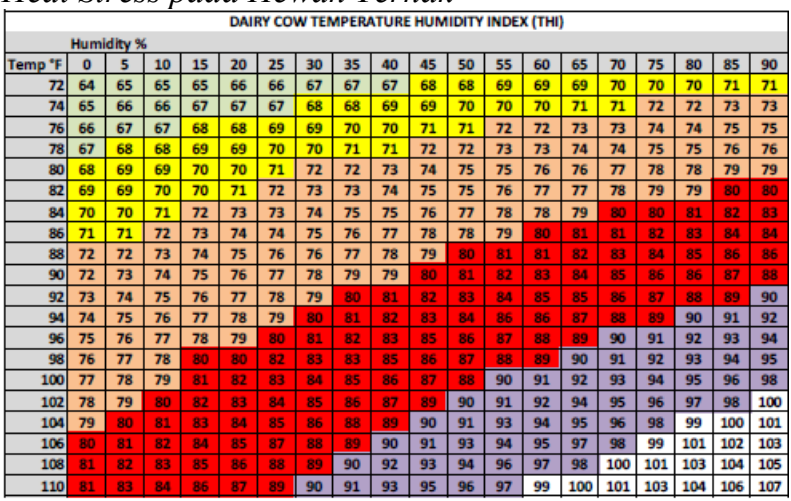

Gambar 2. Matriks Dairy Cow Temperature Humidity Index

Ternak dapat menahan temperatur rendah $-37^{\circ} \mathrm{C}$ tetapi pada temperatur lebih dari $26^{\circ} \mathrm{C}\left(78^{\circ} \mathrm{F}\right)$ dapat menyebabkan stress bila dikombinasikan dengan kelembaban udara yang tinggi, pergerakan udara rendah atau sinar matahari langsung [5]. Berdasarakan pemetaan zona stress pada dairy cow temperature humidity index, heat stress mulai terjadi ketika indeks temperatur $72^{\circ} \mathrm{F}$ pada $45 \%$ kelembaban relatif dan menjadi serius pada temperatur diatas $82^{\circ} \mathrm{F}$ pada $85 \%$ kelembaban relatif. Peningkatan temperatur yang mendadak ketika ternak memiliki sedikit waktu untuk beradaptasi, dapat berpotensi mematikan dan dapat menyebabkan dehidrasi yang cepat.

\section{Panas Gas Buang}

Perhitungan panas gas buang ditentukan dengan mendapatkan estimasi massa gas buang yang diperoleh melalui koreksi terhadap titik optimasi pada kurva engine load dan koreksi terhadap kondisi ambient serta tekanan gas buang sesuai dengan aturan engine maker [6]. Daya yang dihasilkan oleh panas gas buang dapat diketahui dengan persamaan berikut:

$\mathrm{Q}_{\mathrm{exh}}=\rho \cdot \mathrm{C}_{\mathrm{p}} \cdot \Delta \mathrm{T} \cdot \mathrm{V}_{\mathrm{exh}}$

Dimana:

Qexh = Daya yang dihasilkan gas buang $(\mathrm{kW})$

$\rho \quad=$ Massa jenis gas buang $\left(\mathrm{kg} / \mathrm{m}^{3}\right)$

$\mathrm{C}_{\mathrm{p}} \quad=$ Kalor spesifik (kJ/kg.K)

$\Delta \mathrm{T} \quad=$ Perbedaan temperatur $\left({ }^{\circ} \mathrm{C}\right)$

$\mathrm{V}_{\text {exh }}=$ Kapasitas aliran udara gas buang $\left(\mathrm{m}^{3} / \mathrm{s}\right)$

\section{Beban Panas}

Perhitungan beban panas dilakukan dengan menghitung sumber - sumber panas dari ruangan, meliputi panas transmisi $(\varnothing)$, panas radiasi matahari $\left(\emptyset_{s}\right)$, panas dari manusia $\left(\emptyset_{p}\right)$, dan panas lampu penerangan $\left(\emptyset_{L}\right)$. Estimasi perhitungan dalam menentukan beban panas mengacu pada ISO 7574 : Ship and Marine Technology - Air Conditioning and Ventilation of Accomodation Spaces. Total beban panas $\left(\emptyset_{\text {total }}\right)$ dapat dihitung berdasarkan persamaan:

$\emptyset_{\text {total }}=\emptyset+\emptyset_{s}+\emptyset_{p}+\emptyset_{l}$

\section{E. Kapasitas Pendinginan}

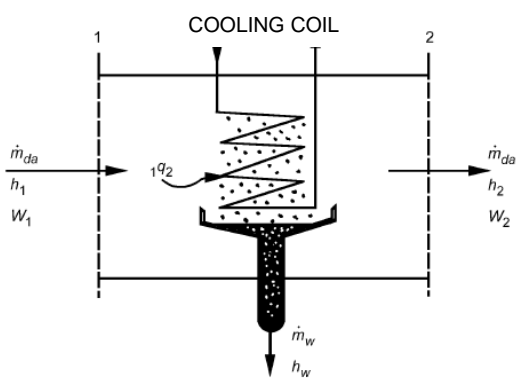

Gambar 3. Skema proses pendinginan

1) Kesetimbangan kalor

$$
\begin{aligned}
\text { Awal }+ \text { Proses } & =\text { Akhir } \\
m_{d a} \cdot h_{1}+\left\{\left(+q+m_{w} \cdot h_{w 1}\right)\right\} & =m_{d a} \cdot h_{2} \\
(+q)+\left(m_{w} \cdot h_{w 2}\right) & =\left(m_{d a} \cdot h_{1}\right)-\left(m_{d a} \cdot h_{2}\right) \\
(+q)+\left(m_{w} \cdot h_{w 2}\right) & =m_{d a} \cdot\left(h_{1}-h_{2}\right) \\
q & =m_{d a} \cdot\left[\left(h_{1}-h_{2}\right)-\left(m_{w} \cdot h_{w 2}\right)\right](3)
\end{aligned}
$$

\section{2) Kesetimbangan massa}

$$
\begin{aligned}
\text { Awal }+ \text { Proses } & =\text { Akhir } \\
m_{d a} . W_{2}+m_{w} & =m_{d a} . W_{1} \\
m_{w} & =m_{d a} .\left(W_{1}-W_{2}\right)
\end{aligned}
$$

\section{METODOLOGI PENELITIAN}

Secara garis besar tahap pengerjaan desain terbagi menjadi tiga. Tahap pertama adalah merencanakan sistem dehumidifikasi dengan menentukan spesifikasi dari rotor desiccant berdasarkan kapasitas udara yang akan disuplai ke dalam ruang muat, kemudian tahap kedua adalah merencanakan sistem pemanas dan pendingin menggunakan alternatif pemenuhan kebutuhan melalui pemanfaatan media pendingin dan pemanas dari peralatan lain, dan langkah terakhir adalah melakukan analisa kesesuaian kondisi desain.

Langkah pertama pengerjaan skripsi ini adalah menentukan skema dan kondisi awal desain sebagai acuan dalam menentukan parameter perhitungan. Selanjutnya yaitu menghitung volume ruang muat kapal berdasarkan gambar rencana umum dan capacity plan serta menentukan nilai air changes per hour sesuai dengan rekomendasi dari GL Annex 1 Ventilation, untuk mendapatkan kapasitas udara yang akan disuplai serta spesifikasi teknis dari rotor desiccant.

Langkah selanjutnya adalah merencanakan kebutuhan sistem pendingin udara hasil dehumidifikasi dan kebutuhan pemanas udara reaktivasi untuk rotor desiccant. Perencanaan kebutuhan sistem pendingin dilakukan dengan menghitung beban pendinginan untuk koil pendingin serta menentukan estimasi kapasitas pendingan yang dapat dihasilkan dengan memanfaatkan media air kondensat mesin AC sebagai pendingin, sedangkan perencanaan pemanas dilakukan dengan menghitung temperatur dan massa gas buang dari main engine untuk mendapatkan daya pemanas. 
Langkah terakhir adalah melakukan analisa kesesuaian kondisi desain. Analisa dilakukan untuk mengetahui apakah desain yang dirancang mampu mempertahankan kondisi ruang muat berdasarkan jenis muatan yang diangkut. Kesesuaian kondisi ruang muat ditentukan dengan mempertimbangkan parameter udara hasil proses dehumidifikasi dan kaitannya dengan kemampuan pendinginan sebelum disuplai ke dalam ruang muat.

\section{ANALISA DATA DAN PEMBAHASAN}

A. Perencanaan Sistem Two-wheel Desiccant

Berikut adalah flow diagram desain sistem two-wheel desiccant yang digunakan:

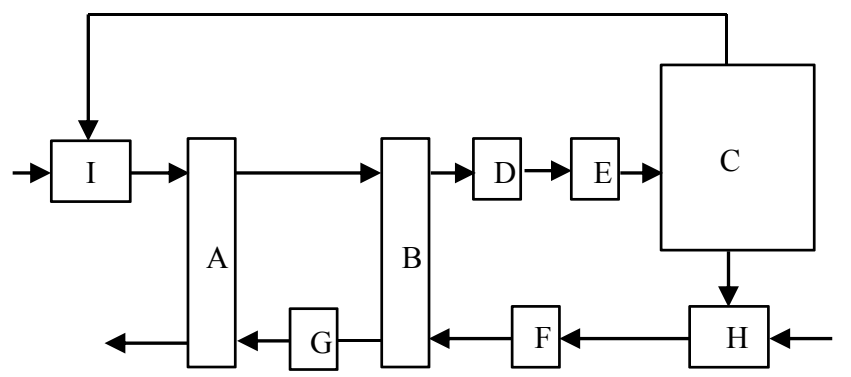

Gambar 4. Flow diagram sistem Two-wheel Desiccant

(A,B: Desiccant wheel; C: Ruang Muat; D: Penukar kalor; E: Koil Pendingin; F: Heater 1; G: Heater 2; H,I: Mixed air)

\section{B. Penentuan Kondisi Desain}

Udara luar pada temperatur $31^{\circ} \mathrm{C}$ dengan $90 \% \mathrm{RH}$ (zona stress berat) akan dikondisikan pada temperatur $26^{\circ} \mathrm{C}$ dengan $50 \%$ RH (zona moderate).

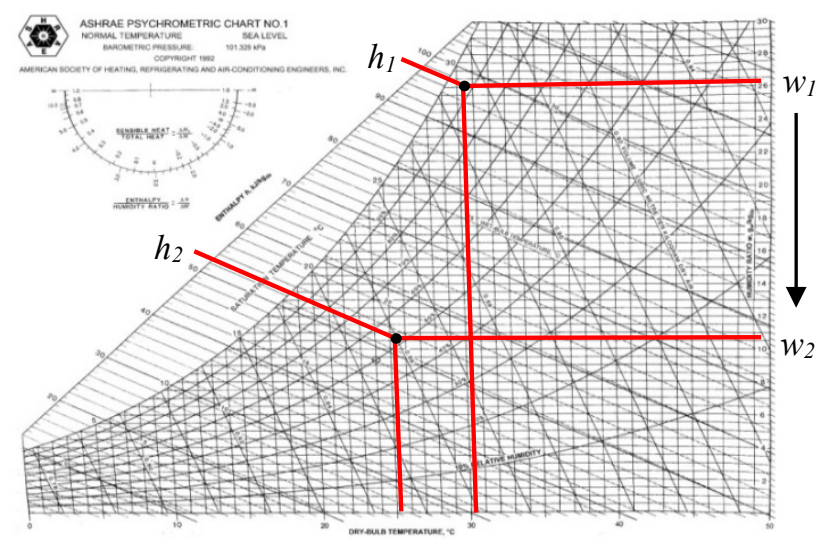

Gambar 5. Grafik Psikrometri proses dehumidifikasi

$\left(h_{1}=97.5 \mathrm{~kJ} / \mathrm{kg}_{\mathrm{da}} ; h_{2}=54.5 \mathrm{~kJ} / \mathrm{kg}_{\mathrm{da}} ; w_{1}=26.1 \mathrm{~g}_{\mathrm{w}} / \mathrm{kg}_{\mathrm{da}} ; w_{2}=\right.$ $\left.10.5 \mathrm{~g}_{\mathrm{w}} / \mathrm{kg}_{\mathrm{da}}\right)$

Humidity ratio, $w_{l}$ sebesar $26.1 \mathrm{~g}_{w} / \mathrm{kg}_{d a}$ akan diturunkan sampai nilainya mendekati $w_{2}$ sebesar $10.54 \mathrm{~g}_{w} / \mathrm{kg}_{d a}$. Analisa pengkondisian udara menggunakan two-wheel desiccant dilakukan dengan bantuan desiccant wheel simulation program untuk mendapatkan spesifikasi wheel yang paling sesuai.
C. Perhitungan Kapasitas Udara Ruang Muat

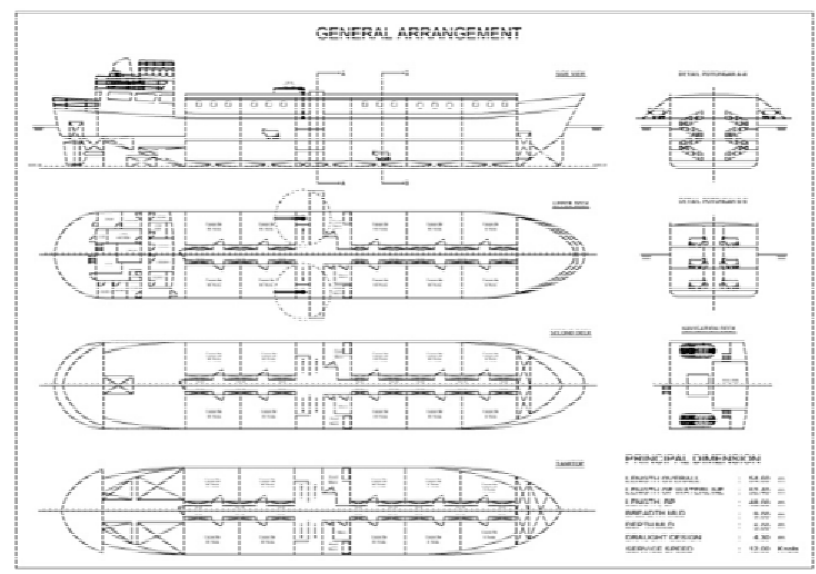

Gambar 6. Rencana Umum Kapal Pengangkut Ternak

Ukuran utama Kapal:

Length overall (Loa) : 54.6 meter

Length of waterline (Lwl) : 52.4 meter

Length between perpendiculars (Lpp): 48.0 meter

Breadth moulded (B) :9.00 meter

Draught Design (T) : : 4.30 meter

Service speed (Vs) : 12 knot

Total volume ruang muat kapal (vol.) berdasarkan data capacity plan adalah sebesar $2061.05 \mathrm{~m}^{3}$. Sedangkan nilai air changes per hour $(n)$ berdasarkan Germanischer Lloyd Annex I Ventilation adalah 20 air changes per hour. Sehingga kapasitas udara $\left(Q_{\text {air }}\right)$ :

$$
\begin{aligned}
Q_{\text {air }} & =n \times \text { vol. } \\
& =20 \times 2061.05 \\
& =41221 \mathrm{~m}^{3} / \mathrm{h}
\end{aligned}
$$

\section{Proses Dehumidifikasi}

Penentukan spesifikasi dari rotor desiccant dilakukan dengan bantuan Desiccant Wheel Simulation Program. Diameter desiccant dipilih berdasarkan aspek ketersediaan ruang pada ruang akomodasi dan kemampuan menurunkan nilai rasio kelembaban. Parameter input untuk menentukan spesifikasi desiccant ditunjukkan pada Tabel 1 berikut:

Tabel 1. Parameter input untuk proses dehumidifikasi

\begin{tabular}{ll}
\hline \multicolumn{1}{c}{ Parameter } & \multicolumn{1}{c}{ Nilai } \\
\hline Process Air Inlet & \\
Air flow & $41221 \mathrm{~m}^{3} / \mathrm{h}$ \\
DB Temperature & $31^{\circ} \mathrm{C}$ \\
Humidity Ratio & $26.1 \mathrm{~g}_{\mathrm{w}} / \mathrm{kg}_{\mathrm{da}}$ \\
Regen Air & \\
T react & $140^{\circ} \mathrm{C}$ \\
R/P Ratio & 0.333 \\
Rotor Information & \\
Desiccant type & $\mathrm{WSG}$ \\
Rotor diameter & $2190 \mathrm{~mm}$ \\
Rotor depth & $200 \mathrm{~mm}$ \\
Rotor velocity & $24 \mathrm{rph}$ \\
\hline \hline
\end{tabular}


Hasil proses dehumidifikasi menggunakan desiccant wheel dengan ukuran $2190 \mathrm{~mm} \times 200 \mathrm{~mm}$ ditunjukkan pada Gambar 7.

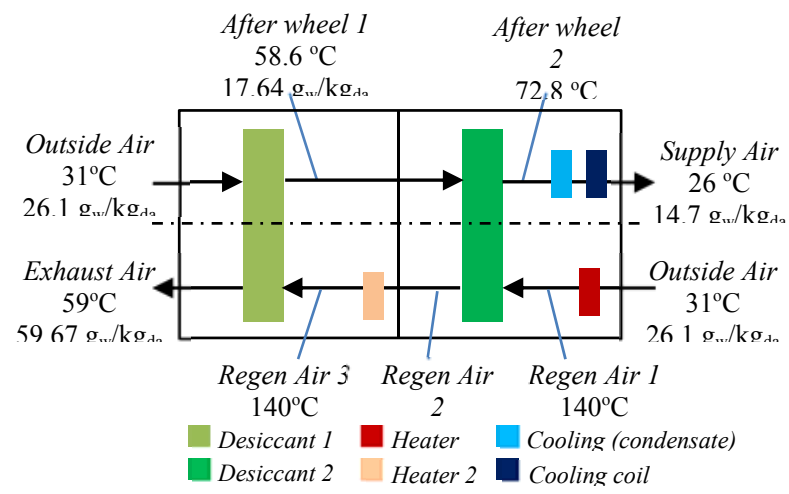

Gambar 7. Proses dehumidifikasi pada two-wheel desiccant

Supply air berada pada temperatur $26^{\circ} \mathrm{C}$ dengan rasio kelembaban $14.7 \mathrm{~g}_{\mathrm{w}} / \mathrm{kg}_{\mathrm{da}}$. Nilai tersebut jika diplotkan pada grafik psikrometri berada pada $69.28 \%$ RH. Parameter tersebut berada pada indeks 74 (zona moderate Temperature Humidity Index), sehingga hasil dehumidifikasi sesuai dengan perencanaan.

\section{E. Perencanaan Kebutuhan Pemanas}

Berdasarkan hasil proses dehumidifikasi, diketahui bahwa kebutuhan temperatur pemanasan untuk kedua rotor desiccant adalah sebesar $140^{\circ} \mathrm{C}$. Aliran udara untuk proses regenerasi dimulai dari desiccant wheel 2 menuju desiccant wheel 1.

Tabel 2. Parameter perencanaan heater 1

\begin{tabular}{ll}
\hline \hline \multicolumn{1}{c}{ Parameter } & \multicolumn{1}{c}{ Nilai } \\
\hline Temperatur udara luar $\left(T_{1}\right)$ & $31^{\circ} \mathrm{C}$ \\
Temperatur udara reaktivasi $\left(T_{2}\right)$ & $140^{\circ} \mathrm{C}$ \\
Temperatur rata - rata & $85.5^{\circ} \mathrm{C}$ \\
Kalor spesifik $\left(C_{p}\right)$ & $1.0086 \mathrm{~kJ} / \mathrm{kg} \cdot \mathrm{K}$ \\
Density $(\rho)$ & $0.9842 \mathrm{~kg} / \mathrm{m}^{3}$ \\
Laju aliran massa $(m)$ & $3.753 \mathrm{~kg} / \mathrm{s}$ \\
Daya pemanas $($ qeater 1$)$ & $412.57 \mathrm{~kW}$ \\
\hline \hline
\end{tabular}

Tabel 3. Parameter perencanaan heater 2

\begin{tabular}{ll}
\hline \hline \multicolumn{1}{c}{ Parameter } & \multicolumn{1}{c}{ Nilai } \\
\hline Temperatur udara luar $\left(T_{l}\right)$ & $97.5^{\circ} \mathrm{C}$ \\
Temperatur udara reaktivasi $\left(T_{2}\right)$ & $140^{\circ} \mathrm{C}$ \\
Temperatur rata rata & $118.75^{\circ} \mathrm{C}$ \\
Kalor spesifik $\left(C_{p}\right)$ & $1.0109 \mathrm{~kJ} / \mathrm{kg} . \mathrm{K}$ \\
Density $(\rho)$ & $0.9007 \mathrm{~kg} / \mathrm{m}^{3}$ \\
Laju aliran massa $(m)$ & $3.434 \mathrm{~kg} / \mathrm{s}$ \\
Daya pemanas $($ q heater 1$)$ & $147.554 \mathrm{~kW}$ \\
\hline \hline
\end{tabular}

Sebagai alternatif pemenuhan kebutuhan pemanas digunakan panas dari gas buang main engine sebagai media pemanas udara reaktivasi. Daya yang dihasilkan oleh panas gas buang diperoleh melalui estimasi perhitungan massa dan temperatur gas buang berdasarkan exhaust gas data dari engine project guide MAN S26MC yang digunakan.

Nominal MCR $\left(L_{l}\right)$,

$P_{L I}: 1600 \mathrm{~kW}(100 \%)$

$n_{L 1}: 250 \mathrm{r} / \mathrm{min}(100 \%)$
Specified MCR (M),

Optimizing Point $(O)$,

Service Rating $(S)$,

Temperatur udara, $\mathrm{T}_{\text {air }}$

Temperatur air pendingin, $\mathrm{T}_{\mathrm{CW}}$

Barometer tekanan, $\mathrm{p}_{\mathrm{bar}}$

Tekanan gas buang, $\Delta \mathrm{p}_{\mathrm{M}}$

Massa gas buang, $\mathrm{M}_{\mathrm{exh}}$

$P_{M}: 1360 \mathrm{~kW}(85 \%)$

$n_{M}: 225.0 \mathrm{r} / \mathrm{min}(85 \%)$

$P_{O}=P_{M}$

$P_{S}: 1280 \mathrm{~kW}(80 \%)$

$n_{S}: 208.9 \mathrm{r} / \min (80 \%)$

$20^{\circ} \mathrm{C}$

$18^{\circ} \mathrm{C}$

1013 mbar

$300 \mathrm{mmWC}$

$13538 \mathrm{~kg} / \mathrm{h} \pm 5 \%$

$14175 \mathrm{~kg} / \mathrm{h}(+5 \%)$

Temperatur gas buang dihitung dengan menggunakan persamaan 2 sehingga diperoleh:

$$
\begin{aligned}
\mathrm{T}_{\text {exh }} & =265+7.2+0+8.8-11.7 \pm 15^{\circ} \mathrm{C} \\
& =237^{\circ} \mathrm{C}+15^{\circ} \mathrm{C}=252^{\circ} \mathrm{C}
\end{aligned}
$$

Massa jenis, $\rho \quad=1.293 \times\left\{\frac{273}{273+T_{e x h}}\right\} \times 1.015 \mathrm{~kg} / \mathrm{m}^{3}$

$$
\begin{aligned}
=1.293 \times 0.52 \times 1.015 \\
=0.683 \mathrm{~kg} / \mathrm{m}^{3}
\end{aligned}
$$

Sehingga kapasitas aliran udara gas buang $\left(\mathrm{V}_{\mathrm{exh}}\right)$,

$$
\begin{aligned}
V_{\text {exh }} & =M_{\text {exh }} / \rho \\
& =14175 / 0.683 \\
& =20754 \mathrm{~m}^{3} / \mathrm{h}=5.765 \mathrm{~m}^{3} / \mathrm{s}
\end{aligned}
$$

Daya dari panas gas buang dihitung dengan persamaan 1 sehingga diperoleh:

$$
\begin{aligned}
\mathrm{Q}_{\mathrm{exh}} & =0.683 \times 1 \times(252-140) \times 5.765 \\
& =440.99 \mathrm{~kW}
\end{aligned}
$$

Daya yang dihasilkan oleh panas gas buang sebesar $440.99 \mathrm{~kW}$ dapat digunakan untuk memenuhi kebutuhan heater 1 sebesar $412.57 \mathrm{~kW}$. Sedangkan kebutuhan untuk heater 2 dipenuhi dengan menggunakan pemanas konvensional.

\section{F. Perhitungan Kapasitas Pendinginan}

Berdasarkan proses dehumidifikasi yang telah dilakukan, temperatur udara setelah melewati desiccant wheel 2 meningkat menjadi $72.8^{\circ} \mathrm{C}$. Temperatur udara ini akan diturunkan menjadi $26^{\circ} \mathrm{C}$ sebelum masuk ke dalam ruang muat. Langkah pertama adalah mencari nilai $m_{d a}$ dengan persamaan:

$\mathrm{m}_{\mathrm{da}}=\frac{\mathrm{Q}}{\mathrm{v}_{3}}$

Dimana:

$$
\begin{aligned}
Q= & \text { kapasitas udara }\left(\mathrm{m}^{3} / \mathrm{s}\right) \\
& =11.45 \mathrm{~m}^{3} / \mathrm{s} \\
v_{3} & =\text { volume spesifik pada } 72.8^{\circ} \mathrm{C}\left(\mathrm{m}^{3} / \mathrm{kg}\right) \\
& =1.0032 \mathrm{~m}^{3} / \mathrm{kg}
\end{aligned}
$$

Sehingga:

$$
\mathrm{m}_{\mathrm{da}}=\frac{11.45 \mathrm{~m}^{3} / \mathrm{s}}{1.0032 \mathrm{~m}^{3} / \mathrm{kg}}=11.41 \mathrm{~kg}_{\mathrm{da}} / \mathrm{s}
$$


Kemudian nilai $m_{d a}$ dimasukkan ke dalam persamaan 3 sehingga diperoleh:

$\mathrm{q}=\mathrm{m}_{\mathrm{da}}\left[\left(\mathrm{h}_{3}-\mathrm{h}_{1}\right)-\left(\mathrm{w}_{3}-\mathrm{w}_{1}\right) \cdot \mathrm{h}_{\mathrm{w} 2}\right]$

Dalam persamaan ini, karena kelembaban udara sudah diserap melalui desiccant, maka tidak terjadi panas laten, sehingga nilai $\mathrm{w}_{3}-\mathrm{w}_{1}=0$

$$
\begin{aligned}
\mathrm{q} & =\mathrm{m}_{\mathrm{da}}\left[\left(\mathrm{h}_{3}-\mathrm{h}_{1}\right)\right] \\
& =11.41[(97.5-54.5)] \\
& =11.41 \times 43 \\
& =490.63 \mathrm{~kW}
\end{aligned}
$$

Kebutuhan pendinginan sebesar $490.63 \mathrm{~kW}$ akan disuplai dengan koil pendingin sebagai pendingin utama. Untuk mengurangi beban pendinginan tersebut, akan dirancang skema pendingin yang memanfaatkan air kondensat dari mesin AC untuk mendinginkan udara hasil proses dehumidifikasi.

\section{G. Perencanaan Sistem Pendingin}

Perencanaan sistem pendingin dimulai dengan menghitung beban panas pada ruang akomodasi untuk menentukan jumlah mesin AC yang akan digunakan, kemudian menentukan estimasi kapasitas air kondensat yang dapat dihasilkan. Setelah memperhitungkan sumber - sumber panas dari ruangan, maka beban panas pada ruang akomodasi dapat ditentukan dengan persamaan 2:

$$
\begin{aligned}
\emptyset_{\text {total }} & =2867.98+28170.34+3310.00+757.86 \\
& =35106.18 \text { Watt } \\
& =35.11 \mathrm{~kW}
\end{aligned}
$$

Penentuan temperatur dan kapasitas air kondensat dilakukan dengan melakukan pengukuran secara fisik terhadap satu unit Air Conditioner (AC) 1 PK. Hasil pengukuran terhadap laju aliran air kondensat ditunjukkan dalam Tabel 4.

Tabel 4. Hasil pengukuran laju aliran air kondensat

\begin{tabular}{cccc}
\hline \hline $\begin{array}{c}\text { Temperatur } \\
\text { Operasional } A C \\
\left({ }^{\circ} \mathrm{C}\right)\end{array}$ & $\begin{array}{c}\text { Volume air } \\
\text { kondensat } \\
(\mathrm{mL})\end{array}$ & $\begin{array}{c}\text { Temperatur } \\
\text { kondensat } \\
\left({ }^{\circ} \mathrm{C}\right)\end{array}$ & $\begin{array}{c}\text { Waktu } \\
(\text { menit })\end{array}$ \\
\hline 16 & 142.5 & 20 & 5 \\
20 & 140 & 20 & 5 \\
24 & 135 & 21 & 5 \\
\hline \hline
\end{tabular}

Pada perencanaan ini, ruang akomodasi dikondisikan pada temperatur $24^{\circ} \mathrm{C}$ sehingga volume air kondensat yang dihasilkan oleh 1 unit AC dalam 5 menit adalah $135 \mathrm{~mL}$. Sehingga kapasitas yang dihasilkan dalam waktu 1 jam adalah:

Kapasitas $\left(Q_{\text {kondensat }}\right) \quad=135 \times 12=1620 \mathrm{~mL} / \mathrm{h}$

Mengacu pada nilai beban panas ruang akomodasi sebesar $35.11 \mathrm{~kW}$, maka jika pemenuhan kebutuhan pendinginan tersebut dipenuhi dengan menggunakan $\mathrm{AC}$ split 1 PK (cooling capacity dibutuhkan adalah:

Unit AC Split

$2.5 \mathrm{~kW}$ ), maka jumlah AC yang $=35.11 / 2.5 \approx 15$ unit

Sehingga, kapasitas yang mampu dihasilkan oleh 15 unit AC adalah:

$Q_{\text {total air }}$ kondensat $\quad=1620 \mathrm{~mL} / \mathrm{h} \times 15=24300 \mathrm{~mL} / \mathrm{h}$

$$
=0.0243 \mathrm{~m}^{3} / \mathrm{h}
$$

Air kondensat akan ditampung dalam tangki insulasi selama 24 jam dengan tujuan mendapatkan kapasitas yang lebih besar untuk digunakan sebagai media pendingin udara hasil dehumidifikasi, sehingga volume air kondensat yang direncanakan $\left(V_{\text {kondensat }}\right)$ :

$V_{\text {kondensat }}=0.0243 \mathrm{~m}^{3} \times 24=0.5832 \mathrm{~m}^{3}$

Tangki dirancang dengan insulasi untuk mencegah kenaikan temperatur air di dalam tangki yang disebabkan oleh heat loss. Perhitungan nilai heat loss dilakukan dengan menghitung koefisien perpindahan panas $(U)$ pada masing masing permukaan tangki [7]. Hasil perhitungan nilai heat loss ditunjukkan dalam Tabel 6.

Tabel 5. Nilai heat loss pada permukaan tangki

\begin{tabular}{ccccc}
\hline \hline \multirow{2}{*}{ Surface } & $\boldsymbol{U}$ & $\boldsymbol{A}$ & $\Delta \boldsymbol{T}$ & $\boldsymbol{q}$ \\
\cline { 2 - 5 } & $B T U / f t^{2} h . F$ & $f t^{2}$ & ${ }^{o} F$ & $B T U / h$ \\
\hline Dry wall & 0.1200 & 8.68 & 19.8 & 20.6253 \\
Wet wall & 0.1693 & 25.10 & 19.8 & 84.1399 \\
Roof & 0.1008 & 15.06 & 19.8 & 30.0564 \\
Bottom & 0.1728 & 8.45 & 19.8 & 28.9012 \\
\hline Total & & 57.28 & & 163.7228 \\
\hline \hline
\end{tabular}

Heat loss dalam waktu 24 jam:

$$
\begin{aligned}
Q_{24 \text { jam }}= & \mathrm{Q}_{\text {total }} \times 24 \\
& =163.7288 \times 24 \\
& =3948.9938 \mathrm{~kJ} / \text { day }
\end{aligned}
$$

Jika diketahui:

$$
\begin{aligned}
m & =581.917 \mathrm{~kg} / \text { day dan } C p=4.1816 \mathrm{~kJ} / \mathrm{kg} .{ }^{\circ} \mathrm{C} \text {, maka } \\
\Delta T & =\frac{Q}{\dot{m} \times C_{p}}=\frac{3948.9938}{581.917^{\circ} \times 4.1816} \\
& =1.62^{\circ} \mathrm{C}
\end{aligned}
$$

Sehingga temperatur air di dalam tangki adalah:

$T_{a k h i r}=21^{\circ} \mathrm{C}+1.62^{\circ} \mathrm{C}=22.62^{\circ} \mathrm{C}$

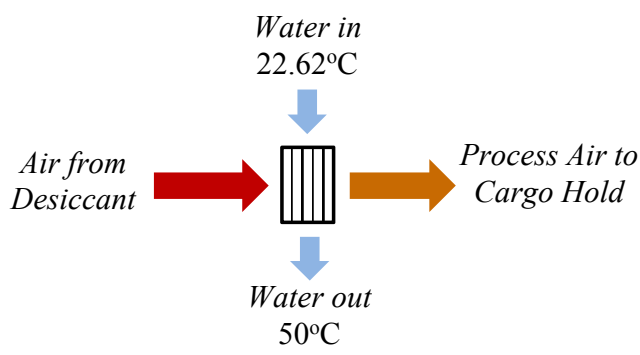

Gambar 8. Skema pendinginan menggunakan air kondensat 
Maka berdasarkan neraca panas diperoleh:

$$
\begin{aligned}
q_{h e} & =m x \operatorname{Cp} x\left(T_{2}-T_{1}\right) \\
& =0.161 \times 4.1783 \times(50-22.62) \\
& =18.41 \mathrm{~kW}
\end{aligned}
$$

Dari hasil perhitungan diperoleh hasil bahwa penggunaan air kondensat mesin AC sebagai media pendingin untuk udara hasil dehumidifikasi dapat mengurangi beban pendinginan cooling coil sebesar $18.41 \mathrm{~kW}$. Nilai tersebut akan semakin besar jika fluida pendingin (air kondensat) dapat disirkulasikan dengan kapasitas yang lebih besar dari nilai kapasitas pada perhitungan.

\section{KESIMPULAN}

Dari hasil perhitungan dan analisa data yang telah dilakukan guna merencanakan sistem ventilasi udara menggunakan two-wheel desiccant, maka dapat disimpulkan bahwa:

1. Dari hasil analisa perhitungan terhadap proses dehumidifikasi volume ruang muat sebesar $2061.05 \mathrm{~m}^{3}$ pada 20 air changes/hour didapatkan spesifikasi desiccant wheel yang paling sesuai dengan diameter 2190 $\mathrm{mm}$ dan ketebalan $200 \mathrm{~mm}$.

2. Rasio kelembaban udara luar pada temperatur $31^{\circ} \mathrm{C}$ sebesar $26.1 \mathrm{~g}_{\mathrm{w}} / \mathrm{kg}_{\mathrm{da}}$ dapat diturunkan menjadi 17.64 $\mathrm{g}_{\mathrm{w}} / \mathrm{kg}_{\mathrm{da}}$ setelah melewati desiccant wheel 1 dan nilainya menjadi $14.70 \mathrm{~g} / \mathrm{kg}_{\text {da }}$ setelah melewati desiccant wheel 2 .

3. Untuk memenuhi kebutuhan pemanas desiccant sebesar $412.57 \mathrm{~kW}$, digunakan panas gas buang dari main engine dengan temperatur sebesar $252^{\circ} \mathrm{C}$ dan menghasilkan daya sebesar $440.99 \mathrm{~kW}$. Sedangkan penggunaan air kondensat sebagai media pendingin dapat mengurangi beban pendinginan sebesar $18.41 \mathrm{~kW}$ dari total kebutuhan pendinginan sebesar $490.63 \mathrm{~kW}$.

\section{DAFTAR PUSTAKA}

[1] Paraya, Lutfi, "Analisa Ventilasi Udara Pada Ruang Muat Kapal General Cargo yang Telah Dikonversi Menjadi Livestock Vessel" Jurnal Ilmiah Teknik Sistem Perkapalan ITS, 2010.

[2] Yulizar, Yusuf, "Perancangan Sistem Pengkondisian Udara Hemat Energi Dengan Menggunakan Desiccant Untuk Ruang Muat Kapal Pengangkut Hewan Ternak (Livestock Vessel)", Jurnal Teknik Sistem Perkapalan ITS Vol. 4, 2013.

[3] Rang Tu, Xiao-HuaLiu , Yi Jiang, "Performance Analysis of a Twostage Desiccant Cooling System", ELSEVIER Journal of Applied Energy 113 (2014) 1562-1574, 2014.

[4] Harriman, Lewis G., "The Dehumidification Handbook Second Edition”, Munters Corporation, Amesbury USA, 2002.

[5] Organic Agriculture of Canada, "Heat Stress in Ruminants", 2010.

[6] MAN Diesel, "Project Guide Camshaft Controlled Two-stroke Engine MAN B\&W S26MC 6 ${ }^{\text {th }}$ Edition”, Copenhagen, 2009.

[7] Jimmy D. Kumana, Samir P. Kothari, "Predict Storage Tank Heat Transfer Precisely", Chemical Engineering Magazine, 1982. 